\title{
THE FREEDOM OF SPEECH AT RISK IN CYBERSPACE: OBSCENITY DOCTRINE AND A FRIGHTENED UNIVERSITY'S CENSORSHIP OF SEX ON THE INTERNET
}

\author{
JEFFREY E. FAUCETTE
}

\section{INTRODUCTION}

On November 8, 1994, Carnegie Mellon University (CMU) removed ${ }^{1}$ a small handful of topics from among the thousands of Usenet newsgroups ${ }^{2}$ subscribed to by the university computer systen 1 and available on the Internet ${ }^{3}$.because they contamed encoded sexually explicit images. ${ }^{4}$ Under the new policy announced by Erwin Steinberg, university vice provost for education, none of the university's 9,000 computers would list the approximately forty newsgroups. ${ }^{5}$ The newsgroups that were censored are all known as "binaries," and they contain, among other things, encoded imag-

1. Despite the University's restriction on the sexually explicit newsgroups, technologically adept students can circumvent the policy by accessing the groups through other file servers. However, for the purposes of this Note, the efforts of these enterprising students are not important when compared with the symbolic effect of the censorship.

2. These newsgroups are "bulletin board-style discussion groups" that can be read from, responded to, and downloaded to an individual's computer. See David Landis, Exploring the Online Universe, USA TODAY, Oct. 7, 1993, at 4D. The Usenet newsgroups are available worldwide via Internet. See id.

3. The Internet is the most commonly known "wide area network" (WAN). It "evolved from networks established by the Department of Defense and the National Science Foundation. [The] Internet connects various government, university, and corporate entities, spans 137 nations, and has at least fifteen million users." Eric Schlachter, Cyberspace, the Free Market and the Free Marketplace of Ideas: Recognizing Legal Differences in Computer Bulletin Board Functions, 16 HASTINGS COMM. \& ENT. L.J. 87, 105 (1993) (citations omitted).

4. See Bill Schackner, CMU Bans Sex Pictures but Delays on Words, PrTTSBURGH POST-GAZETTE, Nov. 8, 1994, at A1. The ban originally extended to newsgroups not containing images, but merely erotic stories and fantasies; however, university attorneys decided the words did not violate Pennsylvania obscenity laws and the final policy did not include the text newsgroups. See Philip Elmer-Dewitt, Censoring Cyberspace; Carnegie Mellon's Attempt to Ban Sex from Its Campus Computer Network Sends a Chill Along the Info Highway, TIME, Nov. 21, 1994, at 102, 103.

5. See Schackner, supra note 4 , at $\mathrm{A} 1$.

6. "Binaries" in the title of the newsgroup indicates that it is primarily devoted to 
es, some of which are potentially "obscene" under the Supreme Court definition of obscemity. ${ }^{7}$ Steinberg claimed that the university's potential criminal hability under Pennsylvania's obscenity laws motivated the decision to ban the newsgroups. ${ }^{8}$

Martin Rimm, a CMU undergraduate majoring in electrical engineering, allegedly prompted the university's action when he advised school officials of the preliminary results of his research on sex and the Internet. ${ }^{9}$ Part of Rimm's research project involved downloading over 900,000 sexually explicit images from various locations on the Internet, including the subsequently censored Usenet newsgroups. ${ }^{10}$ University officials claimed to have been unaware of the availabihty of these images prior to Rinm's report. ${ }^{11}$ The images Rimm found ranged from typical pinup, Playboy-type nude photos to "dogs being raped by men [and] bound woinen being raped by ski poles."12 The notice provided by Rimm was the stated catalyst behind CMU's action to deny access to the images on its computer system. University attorneys told school officials that there was "no doubt that the pictures on the bulletin boards ... . were illegal under state obscenity laws."13

The decision to ban the newsgroups created an uproar on the CMU cainpus. ${ }^{14}$ Calling the ban "the equivalent of closing down a wing of the library," CMU student body president Declan McCullagh vowed to "fight[] the urge to censor."15 Protesting students staged a "Freedom in Cyberspace" rally. ${ }^{16}$

uploaded pictures or sounds. One of the more popular groups banned by CMU is entitled "alt.binaries.pictures.erotica." Elmer-Dewitt, supra note 4, at 103.

7. The Supreme Court outlined the modern three-part test for obscenity in Miller v. California, 413 U.S. 15, 24 (1973). See infra Part II.

8. See Schackner, supra note 4 , at A1.

9. Joshua Quittner, Life in Cyberspace; Computer Sex and the War on Fun, NEWSDAY, Nov. 22, 1994, at 29.

10. See Todd Copilevitz, Techno-Smut on Campus; Carnegie Mellon Limits Students' Access to Erotic Matter, Dallas MoRning News, Dec. 4, 1994, at 3F. Rimm and fellow researchers also concluded that other American users had accessed the images 6.4 million times. See id.

11. See id.

12. George McLaren, Colleges Begin to Limit Access to Pornography on Computer Systems, INDIANAPOLIS STAR, Jan. 1, 1995, at D1 (quoting Erwin Steinberg, vice provost for education at $\mathrm{CMU}$ ).

13. Schackner, supra note 4 , at A1.

14. See Reid Kanaley, College, Students at Odds over Access to Computer Porn, Houston Chronicle, Dec. 18, 1994, at A7.

15. Id.

16. Id. 
The ban also brought the university national attention from the press; the American Civil Liberties Umion; and computer activists such as Mike Godwin, an attorney with the Electromic Frontier Foundation, and Marc Rotenberg, director of the Electronic Privacy Information Center. ${ }^{17}$ The ACLU responded with a letter to the Faculty Senate and Student Council of CMU stating that "[o]ut of fear that your students may be exposed to a few works that a court might ultimately find unprotected, you have cut off access to a large volume of protected ideas and information."18 Attached to the letter was a memorandum outlining CMU's legal position in any potential prosecution and concluding that criminal liabihty for the university was unlikely. ${ }^{19}$ Computer rights orgamzations were especially concerned because of the university's position as a worldwide leader in computer research. ${ }^{20} \mathrm{CMU}$ was an early computer network operator and "was one of the first universities to join the Arpanet (the precursor to the Internet) and the first to wire up its dorms."21 Additionally, the Computer Emergency Response Teain (CERT), an elite virus-battling group, is based at CMU.22 Thus, CMU's actions have the potential to affect access to information on more than just their own computer network..$^{23}$

Because CMU is a private actor, its censorship does not provide an opportunity for judicial recourse under the First Amendment. There is little ground for contending that a private

17. See Schackner, supra note 4, at A1; Bill Schackner, Reinstate Computer Sex Material, ACLU Urges in Letter to CMU Head, PITTSBURGH Post-GAzETTE, Nov. 9, 1994, at B4 [hereinafter Reinstate Computer Sex Material]; Bill Schackner, CMU Handcuffing Cyberspace Sex; Citing State's Porn Laws, School Denies Access to Sexually Explicit Computer Material, PITTSBURGh Post-GazeTre, Nov. 4, 1994, at A1.

18. Reinstate Computer Sex Material, supra note 17, at B4 (quoting letter from ACLU).

19. See Vic Walszak \& Marjorie Heins, Legal Analysis of CMU's Potential Liability for Maintaining Sexually Explicit Bulletin Boards that Contain Obscene Material, November 10, 1994, available over the Internet by anonymous FTP, at FTP.EFF.ORG (Electronic Frontier Foundation).

20. Schackner, supra note 4, at A4.

21. Elmer-Dewitt, supra note 4, at 102.

22. See Copilevitz, supra note 10 , at $3 F$.

23. See Bill Schackner, Pitt Committee Supports Restricting Sex on Internet, PITTSBURGH POST-GAZETTE, December 17, 1994, at B1 (reporting that a panel of faculty, students, and staff recommended that the University of Pittsburgh restrict access to pornography with a policy similar to CMU's). For now at least, the Massachusetts Institute of Technology, another high profile computing university, has indicated that it has no intentions of following CMU's lead. See Copilevitz, supra note 10, at 3F. 
university such as CMU cannot impose content-based restrictions on its own computer network. ${ }^{24}$ However, this does not close the door on useful analysis of the newsgroup ban. For those opposed to censorship of the otherwise entirely unregulated speech on the Internet, the important issues are CMU's real motivations and the impact of Supreme Court obscenity jurisprudence, specifically the Miller test ${ }^{25}$ and the scienter requirements announced in Smith $v$. California ${ }^{26}$ on traditionally protected speech when applied in the nonphysical marketplace of ideas known as cyberspace.

This Note does not advocate the ready availability of pornographic materials, nor does it attempt to defend the content of these sexually explicit images. The First Amendment is both a prohibition on government action and a potent statement of the value this polity places on the freedom of speech. While some of the images found in the censored newsgroups may be disturbing, the First Amendment does not limit its protections only to speech that is soothing; though many people would not clioose to receive the information provided in these banned newsgroups, the choice should still exist. As stated above, although it is unlikely that the First Amendment provides legal recourse against CMU, the university's censorship does violate the values of free speech. This Note assesses the potential legal habilities CMU faces for providing access to sexually explicit newsgroups, and, more importantly, argues that examples sucli as CMU's (un)brave new censorship, on balance, cost society more than they are worth. CMU's action is already lavimg an impact beyond the university's own computer system. Sucl responses threaten to diminish the availability of protected speecl in cyberspace-the first realm where all speakers are equal and where "identity, appearance, [and] possibly even

24. A state-supported university, by contrast, would provide the necessary state action for a First Amendment challenge to such a content-based restriction on speech in a public forum. There is, however, some question as to whether "cyberspace" itself is a public forum in which free speech rights can be asserted. See Edward V. Di Lello, Functional Equivalency and Its Application to Freedom of Speech on Computer Bulletin Boards, 26 COLUM. J.L. \& SOC. PROBS. 199, 201 (1993) (arguing that Prodigy and other computer networks should be "functionally equivalent to the privately owned public forums examined in Pruneyard v. Robins"). But see Edward J. Naughton, Note, Is Cyberspace a Public Forum? Computer Bulletin Boards, Free Speech, and State Action, 81 GEO. L.J. 409, 414 (1992) (examining content restrictions on the Prodigy network and concluding that public forum doctrine should not apply to Prodigy and that "judicial intervention .... is currently unwarranted").

25. Miller v. California, 413 U.S. 15, 24 (1973).

26. 361 U.S. 147, 153 (1959). 
personality, [have] become unimportant."27 Twenty-nine years ago, Justice Potter Stewart best stated the ideal that propels these arguments: "Censorship reflects a society's lack of confidence in itself. It is a hallmark of an authoritarian regime. Long ago those who wrote our First Amendment charted a different course. They believed a society can be truly strong only when it is truly free."2s

Tlis Note begins by taking a close look at the CMU restriction: the material in question, its availability, and its place in the free speech pantheon. Tlie CMU computer censorship debate provides a useful launching ground for analyzing the intersection between sexually exphicit images, modern coinputer network operation, and Supreme Court obscenity jurisprudence. The legal treatinent of computer-transmitted sexually explicit images brings the forefront of technology into conflict with obscenity tests that were formulated twenty and thirty years ago. ${ }^{29}$

Part I presents a brief primer on the Internet and delineates precisely what part of it CMU is attempting to excise froin its network. What the popular media lias described as "smut, men, woinen, animals, devices, down and dirty, in your face, oh-my-God-isthat-what-I-think-it-is-smut, ${ }^{, 30}$ is in reality mostly a lot of hot air, bluster, and run-of-the-mill "cheesecake" and "beefcake" photographs accompanied by the occasional piece of extremely graphic pornograpliy. Censorship of these potentially obscene images must be balanced agamst the larger First Amendment ideals embodied by the free exchange of information on the Internet.

Part II provides a brief overview of modern obscenity doctrine under the First Amendment and the specific questions raised by application of obscenity precedents to computer-transmitted images. Obscenity prosecutions for information obtained through cyberspace highliglit two problems with the Miller obscenity test: (1) defining the applicable "commumity standards" for images up-

27. Eric C. Jensen, An Electronic Soapbox: Computer Bulletin Boards and the First Amendment, 39 FED. COMM. L.J. 217, 224 (1987).

28. Ginzburg v. United States, 383 U.S. 463, 498 (1966) (Stewart, J., dissenting).

29. This Note does not attempt to cover the issue of CMU's potential liability exhaustively. For example, specific realms of liability exist for the distribution of pornographic images of children and for the dissemination of obscene images to minors. While the overall analysis presented in this Note is analogous to these other examples, there are subtle differences at the margins that are not addressed here.

30. Copilevitz, supra note 10 , at $3 \mathrm{~F}$. 
loaded from anywhere in the world and (2) defining the "work, taken as a whole" for an image from a newsgroup containing thousands of postings that are constantly changing. ${ }^{31}$

Part III briefly examines tlie various forms of liability faced by computer network operators for messages and images posted to their systems, and how the different roles system administrators play can affect their potential liability. Currently, a few commentators have posited various theories on which to base system administrator hability; nost of these theories stem from analogies to other areas of more traditional First Amendment jurisprudence. ${ }^{32}$ This Part will also briefly explore Cubby, Inc. v. CompuServe, Inc. ${ }^{33}$ the only reported decision available in the area of computer system operator hability for posted material.

Part IV goes to the heart of CMU's stated explanation for censoring the newsgroups-the notice provided by Rimm's research project. The Suprenie Court first held in Smith v. California ${ }^{34}$ that the Constitution requires some degree of scienter for obscenity prosecutions. The Court further refined this requirement in Mishkin v. New York ${ }^{35}$ and Hamling v. United States. ${ }^{36}$ Given the vagueness of the scienter standard for obscemity prosecutions, however, the impact of CMU's "knowledge" of the sexually explicit images in Usenet newsgroups is unclear. This Part examines this knowledge im light of the Supreme Court's scienter rulings.

In Part V, this Note moves from the constitutional limitations on CMU's liability for sexually explicit images on its computer system to analyze the specific Pennsylvania obscenity statute at issue. In addition to the reasons presented in the otlier Parts, this Note concludes that CMU would not be criminally liable for any sexually explicit image because of the specific statutory definition

31. Miller v. California, 413 U.S. 15, 24 (1973).

32. See Note, The Message in the Medium: The First Amendment on the Information Superhighway, 107 HARV. L. REV. 1062, 1085 (1994) [hereinafter Message in the Medium]; Schlachter, supra note 3 at 116-19; David J. Loundy, E-Law: Legal Issues Affecting Computer Information Systems and Systems Operator Liability, 3 ALB. L.J. SCI. \& TECH. 79, 98-104 (1993); Philip H. Miller, Note, New Technology, Old Problem: Determining the First Amendment Status of Electronic Information Services, 61 FORDHAM L. REV. 1147, 1190-91 (1993); Jensen, supra note 27, at 236.

33. 776 F. Supp. 135, 135 (S.D.N.Y. 1991).

34. 361 U.S. 147, 154-55 (1959).

35. 383 U.S. 502, 511 (1966).

36. 418 U.S. 87,123 (1974). 
of "knowledge" and the specific exemption granted by the Pennsylvania statute itself. ${ }^{37}$

This Note concludes that CMU's fear of successful prosecution and criminal liability is not well-founded. Regardless of whether CMU's restriction was actually motivated by the stated fear of prosecution or by some other content-based reason, ${ }^{38}$ the result is an unnecessary censorship of protected speech and a general chilling effect on other providers of Usenet newsgroup access, particularly other private universities.

\section{THE INTERNET, BINARIES, NEWSGROUPS, AND "TECHNO-SMUT" EXAMINED}

The Internet was born in 1973 when the United States Defense Advanced Research Projects Agency (DARPA) started a program to examine technical methods of interlinking sinaller networks so that research being conducted at multiple locations could be better integrated. ${ }^{39}$ Today, the Internet includes more than 8,000 connected networks, over 1.3 milhon connected computers, and over eight million users worldwide. ${ }^{40}$ Among the resources and functions available on the Internet are electronic mail (enaail), newsgroups, "File Transfer Protocol" (FTP), software, "wide area information servers" (WAIS), "Archie" (an indexing service), "Gopher" (a menu system distributed worldwide that allows information searches), and the World-Wide Web (WWW). ${ }^{41}$ Despite common misconceptions, the Internet is not government-owned, and it remains a generally self-regulating entity. ${ }^{42}$

The Usenet is available to computer network operators via the Internet, and it provides the newsgroups restricted by the new CMU policy. It includes more "than 2,000 newsgroups and more

37. See 18 Pa. Cons. StAT. ANN. \& 5903 (1994).

38. It is possible that CMU simply did not want "techno-smut" available on its computer system. See infra note 156.

39. See V. Cerf, A Brief History of the Internet and Related Networks, available via Gopher at Internet Info.

40. See John S. Quarterman, Internet (1993) available via Gopher.

41. See id.

42. See id. Approximately 18,000 organizations "own" some part of the Internet. Id. The Internet Activities Board (IAB), created in 1983, guides development of the Internet and provides research to all users; it is now organized in two primary components, the Internet Engineering Task Force and the Internet Research Task Force. See Cerf, supra note 39. 
than 2 million users." ${ }^{93}$ Among these thousands of forums, the "alt." (as in alternative) newsgroups tend to be a little more "freeform." ${ }^{\prime 44}$ Users accessing newsgroups are presented with a list of postings. These postings are inessages sent to the group from any user with an Internet connection worldwide. On the various newsgroups, the postings range from one discussion to another, and topics are known as "threads." New users of the newsgroups, referred to somewhat condescendingly as "newbies," are often directed to the "Frequently Asked Questions" file (FAQ), so as not to waste other readers' time and "bandwidth" with repetitive questions or topics. Users who post messages that are off-topic, already covered in the FAQ, insulting or argumentative often receive anywhere froin one to thousands of negative replies (known as "flames"). "Flame wars" can rage out of control on a newsgroup when a particularly disruptive message is posted or when two sides go back and forth on an issue. Among all the Usenet newsgroups, there is one constant-the continuous rollover of messages as new ones are posted and old ones are deleted. Postings to the newsgroups are only temporary, with most postings having lives of anywhere from a day to a week, depending on the volume of postings mailed to the group. In this inanner, the newsgroups attempt to keep discussion flowing and tend to maintain a sense of rough justice among themselves.

These newsgroups, along with other coinputer bulletin boards and services available on the Internet, "provide a significant new channel of communication." 45 In 1919, long before the birth of cyberspace, Justice Oliver W. Holmes wrote that "the best test of truth is the power of the thought to get itself accepted in the competition of the market." ${ }^{46}$ This ideal underlies much of what has been stated and held by the Supreme Court in applying the First Amendment's protection of the freedom of speech. The Internet, with its multitude of newsgroups, nodes, and users, "indi-

43. Quarterman, supra note 40. A USA Today article on the Internet provided a random list of some Usenet newsgroups: "misc.forsale[,] misc.jobs.offered[,] rec.food.cooking[,] rec.arts.startrek.info[,] sci.psychology sci.space[,] soc.culture.african.american[,] soc.feminism[,] talk.politics.drugs[,] ... alt.fan.dave_barry[,] alt.sex.fetishes[,] alt.rock-nroll.metal[,] alt.tasteless[,] alt.supermodels [and] alt.tv.ren-n-stimpy . . . ." Landis, supra note 2 , at $4 \mathrm{D}$.

44. Landis, supra note 2 , at $4 \mathrm{D}$.

45. Jensen, supra note 27 , at 217.

46. Abrams v. United States, 250 U.S. 616, 630 (1919) (Holmes, J., dissenting). 
cate[s] that the goal of a free market in the supply of communications has been better achieved with [computer communications] than in [more traditional methods such as] newspaper[s] or broadcasting ...." With such unregulated communications come the same risks that have always co-existed with free speech.

Unsurprisingly, among the thousands of newsgroups on the Usenet, several are devoted to sexual topics. Indeed, wherever people go in the future in cyberspace or real space, it is unlikely that this topic will ever be eliminated. ${ }^{48}$ A 1994 USA Today article reported that one "monthly compilation of the most trafficked Usenet newsgroups . . . shows that three of the top 10 are sex-related: alt.sex.stories, alt.binaries.pictures.erotica and alt.sex. Each had more than 200,000 readers last month; in some months, readership has topped $400,000 . "{ }^{\prime 4}$ However, the discussions going on in these sexually oriented newsgroups cannot all be cavalierly dismissed as "techno-smut." The The newsgroups also include several threads involving safe sex, responsible sexual conduct, ${ }^{51}$ tolerance for homosexuality, racial tolerance, and equahty between the sexes.

Moreover, the line drawn by the CMU policy between newsgroups like alt.sex and alt.binaries.pictures.erotica on the basis of potential obscenity prosecutions is artificial, ignoring the reality of the contents of these newsgroups. Alt.binaries.pictures.erotica was restricted by CMU because of the sexually explicit images that it contained, as opposed to the mere words in newsgroups such as alt.sex. ${ }^{52}$ However, even binaries newsgroups are not quite what a novice user might expect; accessing a binary newsgroup does not bring a flood of sexually explicit pictures across the monitor. To

47. Jensen, supra note 27 , at 222.

48. Interest in sexually explicit materials has not only spawned increased accessing of Usenet newsgroups but has also been linked to the "growth of the consumer VCR market." See Mike Godwin, Sex and the Single Sysadmin: The Risks of Carrying . . . Graphic Sexual Materials, INTERNET WORLD, March/April 1994, at 56, 57. Moreover, "sexually oriented CD-ROM programs are believed by many to be a hidden factor propelling sales of computers and video game systems." David Landis, Sex, Laws \& Cyberspace Regulating Porn: Does It Compute?, USA TODAY, Aug.l 9, 1994, at 1D, $2 \mathrm{D}$.

49. See Landis, supra note 48, at 1D. Of these tliree, alt.binaries.pictures.erotica is among those banned by CMU. The university originally planned to ban the other two, but then recanted because they usually contain only words and no pictures. See ElmerDewitt, supra note 4, at 103.

50. See Copilevitz, supra note 10 , at $3 \mathrm{~F}$.

51. See Reinstate Computer Sex Material, supra note 17, at B4.

52. See Sclackner, supra note 4 , at A1. 
begin with, the binaries newsgroups sometimes contain almost as many text messages as they do uploaded images. ${ }^{53}$ Typically, the text posts on bimary newsgroups include requests for certain pictures or subjects, comments on previous postings, and more general comments on the newsgroup topic, whether the topic is pictures of erotica or pictures of furniture. ${ }^{54}$

The images themselves are usually denoted by filenames ending in either a ".jpg," ".mpg" or ".gif" suffix indicating which graphic format was used to create the image. However, directing the computer to read a posted image will fill the screen with gibberish. The reason for this seeming nonsense is the limitation on the number of characters (about 90) available on the Internet to depict the colors of pixels in computer pictures; to accommodate these himitations, pictures are "uuencoded" and often broken up into chunks of less than 64 kilobytes. ${ }^{55}$ So, to view these images, three steps are necessary: (1) the uuencoded image must be downloaded to a computer; (2) the uuencoded image must be decoded using a separate application; and finally, (3) the decoded image can be viewed using yet another program. Many of these images, moreover, camot even be printed after viewing because they do not contain enough detail. ${ }^{56}$ Thus, the reality of the "technosmut" banned by CMU is not quite as blatantly "sexy" as the press or the university officials inake it out to be. Moreover, the necessity of taking these steps means that no user will inadvertently view one of these images while accessing a Usenet newsgroup.

The newsgroups contain a treinendous amount of information, both text and uuencoded inages, including some very hard-core pornography that would almost certainly be obscene under the Miller test in most communities and even sonue child pornography that would be illegal regardless of its relative obscenity. ${ }^{57}$ But

53. One of the banned newsgroups, alt.binaries.pictures.erotica.d, while a "binary" group by name, is actually meant to be entirely discussion (as denoted by the " $d$ ").

54. Text posts on binary groups are often followed by complaints (in the form of a text message) from disgruntled users about how this is a binary newsgroup and that text messages should not be posted to it.

55. See Scott Hagie, How to Decode Pics FAQ, available over the Internet, by anonymous FTP, at FTP.NETCOM.COM.

56. See Copilevitz, supra note 10 , at $3 \mathrm{~F}$.

57. In New York v. Ferber, 458 U.S. 747, 756-58 (1982), the Supreme Court held that any pornographic depictions involving children could be restricted on the basis of protecting children from exploitation and abuse. 
removing these potentially illegal images from the newsgroups offered by CMU's computer system also requires removing a great deal of traditionally protected speech. By enacting such a policy, CMU has cast itself as the arbiter of what speech will be allowed and what will not. System operators such as CMU do face the dilemma of determining how to separate the obscenity from the protected speech while "[p]ostings to newsgroups ... flood in over the electronic transom 24 hours a day." $58 \mathrm{CMU}$, however, chose to try to solve the dilemma by censoring altogether the sexually oriented binaries newsgroups. The CMU response overreacts to the perceived threat of possible prosecution. More importantly from the university's perspective, the new policy does not ehminate the risks of potentially obscene images or child pornography on the CMU system. ${ }^{59}$ In fact, no pohicy, short of imdividually reviewing every message posted to a computer system, can completely eliminate the risk of the presence of some "obscene" images. ${ }^{60}$

University officials responsible for the new policy based their decision on the notice provided by Martin Rimm's research. ${ }^{6}$ Notice of the presence of the images prompted the university to restrict the newsgroups, because in any subsequent prosecution, the school could no longer claim a lack of scienter. ${ }^{62}$ Under Supreme Court obscenity doctrime, prosecutions cannot be based on strict liability, but rather require some degree of scienter. ${ }^{63} \mathrm{Al}-$ though the CMU policy restricts otherwise protected speech, ${ }^{64}$ if

58. John Schwartz, School Gives Computer Sex the Boot: Carnegie Mellon University Taking Discussion Groups Off Its Network, WASH. POST, Nov. 6, 1994, at A26.

59. See Godwin, supra note 48, at 61 (noting that "it's always possible for someone to post illegal material to an innocuous newsgroup ... so that it would get to your system anyway"); Message in the Medium, supra note 32, at 1095-96 ("Regardless of the appropriateness of content-based regulations, significant problems will arise in their actual implementation .... In the end, the role of content-based regulations in theory may be irrelevant if such regulations will be unenforceable in practice.").

60. See Godwin, supra note 48, at 61. Additionally, the Electronic Communications Privacy Act of 1986, Pub. L. No. 99-508, 100 Stat. 1848 (codified as amended in scattered sections of 18 U.S.C.), protects an individual's e-mail from inspection without consent, thereby leaving a gaping hole in any system operator's attempt to censor sexually explicit images entirely. 18 U.S.C. $\S \S 2510-2711$ (1988 \& Supp. V 1993).

61. See supra text accompanying notes 9-13.

62. See Schwartz, supra note 58, at A26.

63. See Smith v. California, 361 U.S. 147, 150-54 (1959) (holding that a California statute imposing strict liability on sellers of obscene materials was unconstitutional); see also infra Part IV.

64. Regardless of the protected nature of such speech, there can be no First Amend- 
at least one of the images of which the university received notice is later deemed "obscene" or found to contain child pornography, then the university's knowledge of these contents seems to justify the new restrictions. However, this justification is founded on two assumptions: (1) that the images can be proven obscene and (2) that the notice received by the university provides sufficient scienter for prosecution. These two issues are addressed below in Parts II and III.

\section{THE First Amendment, OBSCENITy, AND THE InTERNET}

The Supreme Court has seen fit to orphan "obscene" expression from the realm of First Amendment protections. ${ }^{65}$ In Miller v. California, the Suprenie Court formulated a three-part test for obscenity that requires exaniming

(a) whether the average person, applying contemporary community standards would find that the work, taken as a whole appeals to the prurient interest ...; (b) whether the work depicts or describes, in a patently offensive way, sexual conduct specifically defined by the applicable law; and (c) whether the work, taken as a whole, lacks serious literary, artistic, political or scientific value. ${ }^{66}$

Applying this test to on-line sexually explicit images creates two primary difficulties. First, it is unclear what the community standard test means when applied to a nonphysical community. Second, it is unclear what information on the Internet would be defined as the "work" in question.

\section{A. "Community Standards" Applied to the Internet}

Computer images contained in Usenet newsgroups can originate from any user in the country (and even the world) who has access to a computer on the Internet. In obscenity trials not involving computer-transmitted images, the question of what "com-

ment claim brought by computer users at CMU since the university is not a state actor. See supra note 24.

65. See, e.g., Miller v. California, 413 U.S. 15 (1973).

66. Id. at 25. This modern test modified the previous test from A Book Named Joln Cleland's Memoirs of a Woman of Pleasure v. Massachusetts, 383 U.S. 413 (1966), by refusing to "adopt as a constitutional standard the 'utterly without redeeming social value'" language from Memoirs. Miller, 413 U.S. at 24-25 (quoting Memoirs, 383 U.S. at 419). 
munity standards" apply has been left intentionally vague under Supreme Court doctrine. ${ }^{67}$ In Jenkins v. Georgia, the Supreme Court reversed a Georgia jury's finding that the film Carnal Knowledge was "obscene". The Court, however, went on to hold that

[w] hat Miller makes clear is that state juries need not be instructed to apply "national standards." We ... agree with the Supreme Court of Georgia's implicit approval of the trial court's instructions directing jurors to apply "community standards" without specifying what "community." Miller held that it was constitutionally permissible to permit juries to rely on the understanding of the community from which they came as to contemporary community standards, and the States have considerable latitude in framing statutes under this element of the Miller decision. A State may choose to define an obscenity offense in terms of "contemporary community standards" as defined in Miller without further specification ... or it may choose to define the standards in more precise geographic terms . ... ${ }^{68}$

Thus, "community standards" are left to the jurors to define in whatever way each juror chooses. This creates a situation where prosecutors shop for conservative venues in which to bring obscenity cases, so that the make-up of the jury will increase the likelihood of application of a conservative commumity standard. ${ }^{69}$

Under "traditional" means of transferring pornography, distributors can purposefully avoid shipping sexually exphicit books, magazines, and videos to communities where they feel they are likely to face prosecution. ${ }^{70}$ Persons in contact with the sexually explicit images have some degree of control over their exposure to potential prosecution, even with the vague "community standards" language of the Miller test. However, applying the traditional community standards test to computer-transmitted images effectively renders that part of the test meaningless.

67. See Jenkins v. Georgia, 418 U.S. 153, 157 (1974).

68. Id.

69. This strategy was demonstrated in the Amateur Action Bulletin Board case. See infra text accompanying notes 70-78. The materials available on the board were confiscated by California law enforcement officials two years prior to the Tennessee case; however, prosecutors did not bring an indictment because the materials did not violate community standards.

70. See Landis, supra note 48 , at $1 \mathrm{D}$. 
The first successful prosecution for computer-transmitted images resulted in convictions for Robert and Carleen Thomas of Milpitas, California. On December 2, 1994, they were sentenced to 37 and 30 months in prison, respectively, for interstate transmission of obscene images to an undercover agent in Tennessee. ${ }^{71}$ The Thomases were operators of the inembers-only Amateur Action Bulletin Board Systein, a commercial bulletin board specifically devoted to sexual topics. ${ }^{72}$ The computer images transmitted by the Thoinases' bulletin board "depicted bestiahity, torture, defecation, self-mutilation and rape."73 The Thomases argued that community standards in Memphis, Tennessee should not be applied to images that were possessed in California; however, U.S. District Judge Juha Gibbons refused to allow the jury to hear this argument. ${ }^{74}$ The decision is currently on appeal, and some commentators beheve that it will not be completely resolved until the Supreme Court decides how the obscenity test should be applied to computer-transmitted inaterial. ${ }^{75}$ The result in the case has left computer systein operators everywhere with fear of prosecution ${ }^{76}$ and may have contributed to CMU's hasty ban of the binaries newsgroups.

The decision in the Thomases' case continues to use the vague approach to the community standards test found in Jenkins $v$. Georgia $^{7}$ while indicating that at least one federal judge is willing to ignore the differences that the new technology of computer bulletin boards brings to the obscenity question. In Miller, the Supreme Court originally based its rejection of a national standard for obscenity on the holding that the Constitution and the First Amendinent do not require courts to ignore the fact that "[p]eople in different States vary in their tastes and attitudes, and this diversity is not to be strangled by the absolutism of imposed unifornity." ${ }^{978}$ In contrast, the logical extension of the decision in the

71. See Computer Porn Nets Prison Terms, Rocky Mountain News, Dec. 3, 1994, at 46A; Landis, supra note 48 , at $1 \mathrm{D}$.

72. See Chris Conley, California Couple Get Prison for Computer Porn Relayed Here, THE COM. APPEAL (Memphis), Dec. 3, 1994, at 1A; Computer Porn Nets Prison Terms, supra note 71 , at $46 \mathrm{~A}$.

73. Conley, supra note 72 , at $1 \mathrm{~A}$.

74. See Computer Porn Nets Prison Terms, supra note 71, at 46A.

75. See Elmer-Dewitt, supra note 4, at 102.

76. See Landis, supra note 48 , at $1 \mathrm{D}$.

77. 418 U.S. 153 (1974); see supra text accompanying notes 67-69.

78. Miller v. California, 413 U.S. 15, 33 (1973). 
Thomases decision means that for computer system operators, the commumity standard is effectively whatever holds true in the most conservative jurisdiction with a phone lime and a computer. This reasoning flies directly in the face of the Miller Court's refusal to adopt a national standard; the fate of this decision hes in the hands of the court of appeals and possibly the Supreme Court. ${ }^{79}$

\section{B. Defining "The Work, Taken as a Whole" in Terms of Usenet Newsgroups}

Upon receiving notice from Martin Rimm that the CMU computer system was home to some potentially obscene images, William Arm, CMU's vice president for computer services, and Erwin Stemberg, vice provost for education, did some investigatimg of their own to determine the nature of the sexually exphicit groups; they found several shocking examples of hard-core pornography. ${ }^{80}$ The umversity promptly banished the newsgroups that contained these images because it feared criminal prosecution under Pennsylvama obscenity law. ${ }^{81}$ For such a prosecution to be successful under the Miller test, the nnages would have to be examined in context because Miller requires that the "work, taken as a whole," be tested. ${ }^{82}$ Thus, one potentially dispositive question im assessing the obscemity of a given innage available on a Usenet newsgroup becomes the definition of the "work."

Defiming the "work" in the Internet context, however, is difficult. Usenet newsgroups to which CMU provides access come as a package containing thousands of constantly changing postings, the majority of which are unlikely to be deemed obscene. CMU's computer system does not provide obscene sexually explicit images as such but does so only inadvertently as a result of providing access to the Usenet newsgroups. Unlike the Thomases' operation of Amateur Action Bulletm Board System, ${ }^{83}$ CMU does not single out any specific images and offer them to users. ${ }^{84}$ Moreover,

79. However, the prosecution of the Thomases does not provide any justification for CMU's censorship. See infra p. 1178.

80. See Schwartz, supra note 58, at A26; McLaren, supra note 12, at D1.

81. See supra Part I.

82. See Miller, 413 U.S. at 24 ; supra text accompanying notes $65-67$.

83. See supra text accompanying notes 71-79.

84. This distinction places the Thomases and CMU on different points on the "sliding scale of control and access" between primary publishers, secondary publishers, and common carriers; these different levels of control account for their different levels of 
because of the ephemeral nature of newsgroup postings, CMU's (and any other Usenet-carrying system administrator's) knowledge of the sexually explicit content of these images only exists in the most general way and can be easily circumvented by posting sexual material in off-topic newsgroups. ${ }^{85}$ The only place on CMU's computer system where actual, decoded, sexually explicit images will be found is in the personal files of individual users, the content of which CMU has no knowledge or control over ${ }^{86}$

In a hypothetical prosecution of CMU for possession or distribution of obscene material via its computer system, logically, the "work" in question to be "taken as a whole" should be the Usenet newsgroup from which the image in question came. The newsgroup is the unit of information that the university deals with when it decides to provide access; Rimm's research put the university on notice as to the content of these newsgroups, and the binaries newsgroups are the "works" that CMU chose to censor. Under the Miller test, the purveyor or distributor of a movie that contained one five-minute, sexually explicit scene in two hours of film would not be liable because, taken in context, the movie would be unlikely to (a) appeal to the "prurient interest" or (b) "lack[] serious ... artistic ... value." of the Miller test is based on a reasonable man standard that does not vary from community to coinmunity. ${ }^{88}$ Similarly, an obscenity prosecution against CMU for possession or distribution of an obscene image or images in one of the newsgroups on its system should require the trier of fact to place the image(s) in the context of the entire newsgroup in question. Only then would the state's interest in prohibiting obscenity be balanced against the cost, measured in terms of protected speech that would be chilled or lost. Such an approach would also insure that the First Amendment would continue to protect "works which, taken as a whole, have serious literary, artistic, political, or scientific value, regardless of

liability. See Schlachter, supra note 3, at 116-19; infra Part III.

85. Rimm's study alerted the university to which newsgroups may tend to contain images likely to be found obscene. But without screening every postiug for content, the university cannot be said to "know" what each group contains at any given moment.

86. See Godwin, supra note 48 , at 60 (citing the protections guaranteed by the Electronic Communications Privacy Act).

87. Miller v. California, 413 U.S. 15, 24 (1973).

88. Pope v. Illinois, 481 U.S. 497, 497 (1987) (holding jury instructions allowing application of community standards to the "value" of the work in question unconstitutional). 
whether the government or a majority of the people approve of the ideas these works represent." ${ }^{\prime 99}$

A prosecutor assigned to the hypothetical obscenity case against CMU would likely argue that the image standing alone should be the work taken as a whole. However, prosecuting a system operator such as CMU under such a theory would seem to implicate the Supreme Court's holding in Stanley v. Georgia, ${ }^{90}$ which protected sexually explicit material in a zone of privacy. ${ }^{91}$ The Stanley Court held "that the First and Fourteenth Amendments prohibit making mere private possession of obscene material a crime." ${ }^{\prime 2}$ In the hypothetical CMU prosecution, the Stanley holding implies that a prosecution based on the sexually exphicit image alone would be prohibited because the only place these images exist in that context is in the personal files of CMU coinputer users. ${ }^{93}$

Neither of the questions regarding the Miller test as applied to computer system operators have been raised in anything other than a hypothetical manner. If the Thomases' case makes it to the Supreme Court, there may then be a refinement of the "community standards" test. The very instability of this area of jurisprudence, however, should not frighten CMU officials into an ill-conceived policy that reduces the amount of free speech available in the marketplace of ideas. Rather, the lack of certainty of such a prosecution should encourage the university to stay the course as a world leader in use of the Internet. Furthermore, even if an image found on CMU's computer systein were deemed obscene, it would

89. Miller, 413 U.S. at 34. Jim Brown, Dean of the School of Journalism at Indiana University-Purdue University at Indianapolis, echoed these thoughts in response to CMU's decision to censor its computer system: "There's some really gross stuff out there, by most people's staudards. It makes you wonder about the mentality of some people ... [, but a]s an academic, I recognize that my trash is another person's research material ...." McLaren, supra note 12 , at D1.

90. 394 U.S. 557 (1969).

91. Id. at 566 (holding that "[w]hatever the power of the state to control public dissemination of ideas inimical to the public morality, it cannot constitutionally premise legislation on the desirability of controlling a persou's private thoughts").

92. Id. at 568 .

93. Although Jenkins has never been applied to the private possession of computer files, the difference in technology between film and computer disk or memory would not appear to be dispositive in such a case. 
still be extremely unlikely that the umversity would face criminal liability. ${ }^{94}$

\section{DIFFERING DEGREES OF LIABILITY FOR SYSTEM ADMINISTRATORS}

Previous analysis of system administrator liability for the actions or statements of others posted on computer networks has been largely confined to liability for traditional tort actions such as defamation or hibel..$^{95}$ These examinations of vicarious liability for postings by those otlier than the system operator have generally proceeded by analogizing the role of the system administrator to that of more traditional First Amendment actors. Because computer networks offer "a number of communication options[,] . . one analogy is insufficient." Network operators face a "sliding scale" of analogous roles running from primary publislier to secondary publisher to common carrier. ${ }^{97}$ To determine CMU's potential liability, it is necessary to examine first where the university falls on this scale of computer system operators.

As primary publishers, system admimistrators liave rights and responsibilities similar to other, more traditional media outlets. ${ }^{93}$ The Supreme Court established the extent of such a publisher's liability for defamation in New York Times v. Sullivan ${ }^{99}$ when it held that plaimtiffs must slow actual malice to recover.$^{100}$ Secondary pubhishers differ in that they do not have editorial control over content; such publishers generally cannot be held liable for the defamatory (or obscene) nature of the material they publish. ${ }^{101}$ Third, "common carriers[] such as telephone companies ... and other non-content providers ... also lack substantial editorial

94. See infra Parts III, IV, and V.

95. See Schlachter, supra note 3, at 116-19; Jensen, supra note 27, at 243-52.

96. Loundy, supra note 32 , at 89.

97. See Schlachter, supra note 3, at 116-19; see also Loundy, supra note 32, at 88-89.

98. See Jensen, supra note 27, at 243-44 (citing Legi-Tech, Inc. v. Keiper, 766 F.2d 728 (2d Cir. 1985), in support of the proposition that in some circumstances computer network operators should be treated as media outlets with the same rights and liabilities under the First Amendment).

99. 376 U.S. 254 (1964).

100. Id. at $279-80$.

101. See Schlachter, supra note 3 , at $115-16,118$ (stating that secondary publishers will be held liable only if they "knew or had reason to know of the existence of defamatory material"). 
control and generally are considered immune from hability for the statements of others . . ."102

In addition to the scale of roles of system administrators, different computer network operations entail another set of analogies that nıy also result im different levels of potential hability. ${ }^{103}$ Message posting - such as to Usenet newsgroups, e-mail, real-time interaction among multiple users, information resources and databases, software dissemination, and gateways to other systems-are all different functions that computer networks can provide to users. ${ }^{104}$ By combining the scales of type of function and type of control, one commentator has suggested that system operators "can choose the level of knowledge and control they want, with the conconitant rights and responsibilities."105 The Prodigy network is a good example of this choice in the real world. ${ }^{106}$ Prodigy, which has over one million users and claims to be the largest of the commercial bulletm board services, ${ }^{107}$ bills itself as the "Disney Channel" of computer networks ${ }^{108}$ and "states that it is responsible for its users' messages and therefore has the rights of a print publisher not to print every message submitted."109 By taking this position, Prodigy takes on the responsibility for all publicly posted messages on its system and assumes any potential liability stenıming fronı such messages. ${ }^{110}$

CompuServe, another of the commercial bulletm board services, takes a different approach to its responsibilities as a network operator: it removes messages only after complaints from other users. ${ }^{111}$ CompuServe was a defendant in Cubby, Inc. v. CompuServe, Inc., ${ }^{112}$ currently the only federal case against a bulletin board operator based on the content of third party postings. In Cubby, the plaimtiffs brought suit agaimst CompuServe for libel,

102. Id. at 119.

103. See id. at $129-47$.

104. See id. at 108-10.

105. Id. at 147.

106. See Naughton, supra note 24 , at $409-12$.

107. Landis, supra note 2 , at $4 \mathrm{D}$.

108. Schlachter, supra note 3 , at 102 n.53.

109. Id. at 136. Prodigy prescreens submitted messages by using an automated program that searches for key words. See id. at 102 n.54.

110. See id. at 137.

111. Id. at 136.

112. 776 F. Supp. 135 (S.D.N.Y. 1991). 
business disparagement, and unfair competition. ${ }^{113}$ The statements that prompted the suit were made in the "Journalism Forum," one of many such forums offered by CompuServe. ${ }^{114}$ CompuServe contracts out to various suppliers for the information contained in these forums, and in this particular case, the contract between CompuServe Information Services and Cameron Communications, Inc. (CCI) gave exclusive rights to "'manage, review, create, delete, edit and otherwise control the contents' of the Journalism Forum 'in accordance with editorial and teclımical standards and conventions of style as established by CompuServe." "115 The court granted CoinpuServe's motion for summary judgment in the case and held that CompuServe was merely a "distributor" of information, and as such could not be held liable for defamatory statements absent a slowing that it knew or had reason to know of the defamation. ${ }^{116}$

CMU's role in providing access to Usenet newsgroups under this type of analysis indicates that CMU would likely be held to be a "mere distributor" of the information on the newsgroups. The system operators at $\mathrm{CMU}$ do not exercise any editorial control over the individual postings in the Usenet newsgroups nor does the university explicitly clain any responsibility for the contents of those postings. As a distributor, CMU's tort and criminal liability for the contents of these newsgroups is limited only to the material about which CMU knew or had reason to know. This scienter standard is at the root of CMU's explanation of its censorship of the newsgroups. However, as explained in Part I, CMU did not actually have knowledge of any particular sexually explicit image; it only knew that some newsgroups had contained potentially obscene images in the past. To determine fully whether CMU's knowledge (or lack thereof) warrants its stated fear of prosecution requires an examination of the Supreme Court's scienter standard for obscemity prosecutions.

113. See id. at 137.

114. See id.

115. Id.

116. Id. at 139 (citing Lerman v. Chuckleberry Publishing, Inc., 521 F. Supp. 228, 235 (S.D.N.Y. 1981)). In granting the motion, Judge Leisure made reference to Smith v. California, 361 U.S. 147 (1959), in support of the knowledge requirement for the defamation cause of action. See id. at 139. The Smith decision and an application of its scienter requirements in obscenity prosecutions are covered fully in Part IV. 


\section{THE SMITH SCIENTER REQUIREMENT AND OBSCENITY PROSECUTIONS}

A successful obscenity prosecution requires first that the material in question be proven to be obscene under the Miller test. ${ }^{117}$ At common law, all criminal prosecutions required proof of some degree of mens rea. ${ }^{118}$ However, defendants in obscemity prosecutions may not raise as a defense the lack of knowledge that the material in question was "obscene" according to community standards under the Miller test. ${ }^{119}$ This chilhing effect on material at the margin of obscenity was hfted soniewhat by the Supreme Court in 1959 in Smith v. California. ${ }^{120}$

In Smith, a bookseller in Los Angeles was convicted for violating a nuunicipal ordinance "which [made] it unlawful 'for any person to have in his possession any obscene or indecent writing, [or] book ... in any place of business where ... books ... . are sold or kept for sale." "'21 Since the definition of the offense in the ordimance did not include any requirement that the person charged have any knowledge of the contents of the book or material, the Court construed the ordinance as imposing "strict" hability. ${ }^{122}$ The Court held that the imposition of strict hability by the lack of a scienter requirement in the ordinance "would tend seriously to have [the effect of restricting the dissemination of books that are not obscene], by penalizing booksellers, even though they had not the slightest notice of the character of the books they sold." 123 This chilling effect on booksellers caused by the ordinance would then tend "to impose a severe limitation on the pub-

117. See supra Part II.

118. See Staples v. United States, 114 S. Ct. 1793, 1797 (1994). In Staples, Justice Thomas restated the oft-quoted line from Dennis v. United States, 341 U.S. 494, 500 (1951): "The existence of a mens rea is the rule of, rather than the exception to, the principles of Anglo-American criminal jurisprudence." Id.

119. See Hamling v. United States, 418 U.S. 87, 123-24 (1974) (liolding that the government does not have to prove defendant's knowledge of the "legal status" of the inaterial in question); see also WILLIAM W. VAN ALSTYNE, FIRST AMENDMENT 676-77 (1991) (noting that "[s]ince so inuch rides on the right guess respecting the nonobscenity of the material in question, one's uncertainty may per se produce a large chilling effect").

120. 361 U.S. 147 (1959); see VAN ALSTYNE, supra note 119, at 677.

121. Smith, 361 U.S. at 148 (alteration in original) (quoting $\S 41.01 .1$ of the Municipal Code of the City of Los Angeles).

122. See id.

123. Id. at 152 . 
lic's access to constitutionally protected matter."124 Thus, the Court held that obscenity laws must lave some scienter element; ${ }^{125}$ however, in an additional dictum the Court stated that they "need not and most definitely do not pass today on what sort of mental element is requisite to a constitutionally permissible prosecution of a bookseller for carrying an obscene book in stock." 126

The Supreme Court later refined the level of scienter necessary for a constitutionally permissible obscenity prosecution in Mishkin v. New York ${ }^{127}$ and Hamling v. United States. ${ }^{128}$ In Mishkin, the Court upheld a conviction under a New York state obscenity law that was interpreted as requiring that the defendant be "aware of the character of the material."129 In Hamling, the Court held that "[i]t is constitutionally sufficient that the prosecution show that a defendant had knowledge of the contents of the materials he distributed, and that he knew the character and nature of the materials." 130 The Court did not offer any elaboration of the meaning of these phrases or their potential application. ${ }^{131}$ The Court also lield that the prosecution did not have to prove that the defendants knew of the "obscene cliaracter of the niaterial." 132

Applying only this scienter standard to CMU's knowledge of the contents of the censored Usenet newsgroups does not yield absolutely clear answers. ${ }^{133}$ At one extreme, CMU clearly would have the constitutionally necessary scienter in a prosecution involving one of the specific images pointed out by Rimm to university officials. At the other extreme, the university clearly could not be constitutionally held hable for an obscene iniage found posted offtopic in a newsgroup such as rec.sports.basketball.college. The

124. Id. at 153 .

125. Id. at 154-55.

126. Id. at 154; see also Jensen, supra note 27, at 248-49.

127. 383 U.S. 502 (1966).

128. 418 U.S. 87 (1974).

129. Mishkin, 383 U.S. at 510-11. See Recent Development, Federal Child Pornography Law's Scienter Requirement-United States v. X-Citement Video, Inc., 28 HARV. C.R.-C.L. L. REV. 585, 590 (1993).

130. Hamling, 418 U.S. at 123 (emphasis added).

131. Recent Development, supra note 129 , at 590.

132. See Hamling, 418 U.S. at 120.

133. The uncertainties expressed in various parts of this Note are not cumulative, i.e., they do not total up to imply a reasonable fear of prosecution for CMU. 
reahty of the situation is somewhere in between: CMU knows, as do all system operators, that at any one time it is likely that some of the Usenet binaries newsgroups contain sexually explicit images that are potentially obscene. ${ }^{134}$

In Smith, the defendant was a bookseller operating a small booksliop, and the Supreme Court's decision reflected a recogmition of the limitations that the defendant faced in knowing the contents of his stock; this factual situation has been compared to that of the small computer bulletin board operator. ${ }^{135}$ The positions of the two parties are rouglly equivalent in terms of their abihty to monitor the contents of the material they offer. ${ }^{136}$ Using this sort of comparison as an example, one commentator has argued unpersuasively that the Supreme Court's vague "constructive" knowledge requirement for obscenity prosecutions strikes the proper balance between protecting free speech and protecting society. ${ }^{137}$

In contrast to the sinall bulletin board operator, CMU's network comprises over 9,000 computers with access to thousands of Usenet newsgroups, thousands of FTP servers worldwide, and millions of computer users through e-mail. Permitting prosecutors to use a constructive knowledge standard against such a computer operator renders the stated goals of the Smith standard meaningless. To say that "[w]hile the operator should not be found liable for occasional acts of users, proof that a board is consistently used for illegal activities should be sufficient to impose liability" ${ }^{138}$ is to ignore the very dangers of clilling protected speecl of which the Court warned in Smith. ${ }^{139}$ However, other more contemporary commentators have argued that, for the purposes of liability, system operators should not be deemed to have "'knowledge' unless they have actual knowledge . . .."140 Under an "actual knowl-

134. See supra Part II.

135. See Jensen, supra note 27 , at 248.

136. See id.

137. See id. at 249. The assumptions that Jensen made in 1987 about the ability of system operators to monitor content are somewhat outdated given the rapid expansion of commercial networks and the explosive growth of the Internet over the past eight years. Currently, a system administrator such as CMU faces a tremendously greater burden than the average bookseller in terms of the amount of material that potentially might have to be inonitored.

138. Id.

139. See Smith v. California, 361 U.S. 147, 152-54 (1959).

140. Schlachter, supra note 3, at 134 (emphasis added); see also Loundy, supra note 
edge" standard, CMU would be liable only for those sexually explicit images of which it had actual notice-namely those images found by Rimm and slown to university officials.

Any prosecution of $\mathrm{CMU}$ for obscene images on its computer network most likely would be decided under the Hamling scienter standard. No Supreme Court or circuit court precedent exists involving the imposition of tort or criminal liability on a computer system operator. The two recent lower court cases examined above, Cubby, Inc. v. CompuServe, Inc. and the Thomases decision, lowever, do provide CMU with avenues of defense against such a prosecution. ${ }^{141}$ Following the line of reasoning applied in Cubby, CMU slould not be liable for the contents of any Usenet newsgroup because it is inerely distributing those newsgroups as a whole; coinputer networks that subscribe to the Usenet generally do not exercise any editorial control over the content of the individual newsgroups. ${ }^{142}$

The Thoinases decision should also provide CMU with legal arguinents against liability for obscene innages because the Thomases' position can be readily distinguished from CMU's. Through their Amateur Action Bulletin Board Systein, the Thomases were actively engaged in the business of transmitting pornography to subscribers. The role that the Thomases played as system operators was mucli closer to that of a primary publisher as opposed to CMU's position as a inere distributor. Thus, the Thomases' potential hability far outstrips that of the university, and the Thomases' case would provide a useful contrast for CMU in any hypotlietical prosecution.

Thus far, this Note has examined the constitutional issues involved in CMU's potential liability under obscenity law without focusing on the specifics of Pennsylvania's obscenity statute. This approacl has been used to provide a generally applicable analysis of computer network operator hability for sexually explicit images and to assess the reasonableness of the university's expressed fear. Overall, this Note is concerned more witl the broader ramifications of CMU's actions than with delving into the minutiae of

32 , at $138-40$.

141. For discussion of Cubby, see supra text accompanying notes 111-16; for discussion of the Thomases decision, see supra text accompanying notes 71-75.

142. Ironically, the censorship of the binaries newsgroups may actually diminish the force of this argument since CMU is clearly attempting to take control of some content, albeit in a very clumsy and heavy-handed way. 
Pennsylvania obscenity law. However, certain specific sections of the Pennsylvania statute further undermine CMU's stated fear and may provide other similarly situated computer system administrators with the modicum of courage that Carnegie Mellon lacked.

\section{CMU'S POTENTIAL LIABILITY UNDER PENNSYlVANIA OBSCENITY LAW}

This Part presents a brief examination of the extreme untikehhood of success for such a specific prosecution under 18 PA. CoNS. STAT. ANN. § 5903. When Erwin Steinberg, vice provost for education at Carnegie Mellon, made the announcement that CMU would be banning certain sexually explicit newsgroups from the university's computer systen, the priniary reason offered was the university's new-found fear of an obscenity prosecution. ${ }^{143}$ Assessment of the university's stated explanation among various commentators, mcluding computer activists, the ACLU, and CMU students, ranged from mere honest mistake to subterfuge for elininating distasteful material on the basis of content. ${ }^{144}$ As this Note has argued, any actual obscenity prosecution of the university would face several constitutional difficulties and would have, at most, an extremely small chance of ultinnate success. ${ }^{145}$ However, as the ACLU pointed out in its memorandum to the university, specific aspects of the Pennsylvania obscenity law make the likelihood of successful prosecution even closer to zero. ${ }^{146}$

Pennsylvania's obscenity statute ${ }^{147}$ prohibits any person "knowing the obscene character of the materials . . mvolved"148 from, among other things, "distribut[ing] ... to any person 18 years of age or older... any obscene materials in any manner." 149 The definitional section of the statute states that "knowing means having general knowledge of, or reason to know or a behef or ground for behef which warrants further inspection or inquiry of, the character and content of any material ... which is

143. See Schackner, supra note 4 , at A1.

144. See supra text accompanying notes 14-23.

145. No university anywhere in the United States has ever faced such a prosecution. See Walszak \& Heins, supra note 19.

146. See id.

147. 18 PA. CONS. STAT. ANN. \& 5903 (1994).

148. Id. \& 5903(a).

149. Id. $\S 5903(\mathrm{a})(2)$. 
reasonably susceptible of examination by the defendant"; the statute also uses the Miller test as the definition of "obscene."150 The "behef" language used in Pennsylvania's definition of knowledge appears to be less protective than the Suprenie Court's formulation of "knowledge of the contents of the niaterials . . . , and ... [knowledge of] the character and nature of the materials." 151 However, by limiting the inaterial in question to that "which is reasonably susceptible of examination," the statute may actually be more protective than the standard that the Supreme Court has held is constitutionally required. Given that there are thousands of continuously changing postings on the Usenet newsgroups that CMU has restricted, it would be at least very difficult, if not impossible, for a prosecutor to prove that a single image or a handful of images were "reasonably susceptible of examination."152 As was stated more generally above, the knowledge standard necessary for a constitutional obscenity prosecution reduces the likelihood of any such prosecution against CMU. ${ }^{153}$

Furthermore, the Pennsylvania statute offers the university another escape from criminal hability. Subsection (j) of the statute explicitly provides the following exemption from prosecutions: "Nothing im this section shall apply to ... any library of any school, college or university ...."154 While the university's entire coniputer network may not be contained within the physical walls of the campus hibrary, the system is functioning in effect as an electronic hibrarian, providing campus-wide access to a nultitude of resources, among which is the Usenet newsgroups. ${ }^{155}$ No reported case in Peimsylvaina has interpreted this exeniption, so the likelihood that CMU's computer system would fit the definition of "library" is difficult to gauge. These two exemptions in the Pennsylvania statute offer additional reasons for CMU to abandon its pohicy of censoring Usenet newsgroups.

150. Id. § 5903(b) (emphasis added).

151. Hamling v. United States, 418 U.S. 87, 123 (1974).

152. See Walszak \& Heins, supra note 19.

153. See supra Part IV.

154. 18 PA. CoNs. STAT. ANN. \& 5903(j) (1994).

155. Walszak \& Heins, supra note 19. 


\section{CONCLUSION}

For the first time since the adoption of the First Amendment, the theoretical dream of a free marketplace for ideas has become a reality. The Internet and the thousands of smaller computer networks that have sprung up across the United States provide anyone with access to a computer the opportunity to air his views on almost any subject imagmable. This technology is still $\mathrm{m}$ its infancy, but lias managed to grow and thrive so far virtually unregulated by government, school, or business. Previously, Carnegie Mellon University was a powerful supporter and developer of the Internet. Every dorm on campus, and even some of the bathrooms, have access to the university's computer system, which in turn provides access to the world through the Internet. Unfortunately, this access was recently curtailed by university officials who were supposedly fearful of prosecution under Peimsylvania's obscemity law.

At the root of this fear is the Supreme Court's decision that obscenity is not speech and thus is not protected by the First Amendment. This decision, however, is bounded by the definition of "obscenity" and by the requirements of scienter. Obscenity law was never meant to subject the entire nation to the standards of the most conservative jurisdiction in the country. The problem arises because these legal doctrines were formulated in a world of magazines, books, and film. Their application to a new technology that is functionally without a physical "community" has the potential to put a tremendous chill on the exchange of free speech in cyberspace and has resulted indirectly in the restriction of protected speech under the new CMU policy.

Instead of bowing to the pressure that the tension between this new technology and old jurisprudence creates, CMU should have demonstrated courage and a renewed support for the freedom of speech. Adimittedly, a few of the images available on Usenet newsgroups are offensive, disgusting, vile, and reprehensible to the majority of Americans; however, the cost of eliminating them places too great a burden on protected free speecli and places an intolerable linnitation on the free flow of information on the Internet. CMU's censorship is legal because of the private nature of the institution and the university's authority to control access on its coinputer system in whatever manner it so cliooses. As this Note has argued, however, the explanation that CMU officials 
have offered for this act of censorship is almost entirely baseless. ${ }^{156}$ If the umiversity officials were sincere, then their explanation merely exhibits a complete lack of courage in the university's free speech convictions. If, on the other hand, the excuse was a subterfuge to hide a content-based reason behind the ban, then the university deserves to be roundly condemned by any and all true advocates of the First Amendment and free speech in the United States.

156. One of these officials, Erwin Steinberg, recently spoke at the Frontiers of Legal Thought Conference at Duke University School of Law. While his comments did not represent the university's official position, Vice Provost Steinberg stated two previously unmentioned reasons for the CMU restrictions: (1) the offensive nature of the images and (2) a concern for the reactions of various university sources of private funds and support. See Vice Provost Erwin R. Steinberg, Address at the Frontiers of Legal Thought Conference (January 27, 1995) (remarks available from Carnegie Mellon University). 